CFaculty of Veterinary Medicine, Zagazig University, 44511, Egypt

DOI: 10.21608/zviz.2017.7939.

\title{
Prevalence of Chlamydophila psittaci in some Wild and Pet Birds
}

\author{
Ahmed M. Hegazy ${ }^{1}$, Mohamed A. El-sisi ${ }^{1}$, Ola Hassanin ${ }^{1}$, Hala M.N. Tolba ${ }^{1}$ and Heba A. Baz ${ }^{2 *}$ \\ ${ }^{1}$ Avian and Rabbit Medicine Department, Faculty of Veterinary Medicine, Zagazig University, \\ 44511, Egypt \\ ${ }^{2}$ The Veterinary Hospital, Faculty of Veterinary Medicine, Zagazig University, 44511, Egypt \\ Article History: Received: 28/12/2016 Received in revised form: 27/7/2017 Accepted: 1/9/2017
}

\begin{abstract}
Chlamydophila psittaci is one of the most important, zoonotic pathogen of birds causing chlamydiosis. This study aimed to investigate the frequency of infection by $\mathrm{Cp}$. psittaci and to determine the genotype in birds at potential risk of exposure to this pathogen. In total four species of wild birds (50 native and 40 migratory quails, 30 doves and 25 tree sparrows) and four species of pet birds, (20 Budgerigars, 10 cockatiels, 3 finches, 5 love birds) were examined for the presense of Chlamydophila psittaci using impression smears stained with Giemsa stain, smears from yolk sacs were stained with Gimenez stain and PCR. The results were $(80 \%$ $100 \%),(85 \%-100 \%)$ and $(80 \%-100 \%)$ in pet birds followed by wild birds $(64 \%-85 \%),(76 \%-$ $95 \%)$ and $(80 \%-90 \%)$, respectivelly The pathogencity of three isolates by intratracheal route with $10^{6} \mathrm{TCID} / \mathrm{ml}$ in 15 days old chickens and quails was done and showed that the more pathogenic strain for chickens and quails was the pet birds strain. The observed clinical signs were respiratory signs, conjunctivitis, and diarrhea, While the pathological changes were congestion in liver, lung, spleen, and pericarditis while mild clinical and pathological changes were observed post infection by tree sparrows and migratory quails isolates. The partial ompA gene sequence of isolated $C p$. psittaci strain was placed in genotype A of $C p$. psittaci which had the highest identity (91.9-94\%) with previously similar described strains of genotype A. Pet and wild birds were the major reservoir for $C p$. psittaci which shed in their excreta and expose human and native birds to high zoonotic risk.
\end{abstract}

Keywords: $C p$. psittaci, Wild Birds, Pet Birds, ompA Gene

\section{Introduction}

Chlamydiosis, known as parrot disease, parrot fever, ornithosis or psittacosis is a widespread disease caused by Chlamydophila psittaci which is an intracellular, Gramnegative, coccoid bacterium causing a reportable zoonotic disease in many countries $[1,2]$.

A special feature of Chlamydophila is that it has a biphasic life cycle, existing as elementary, reticulate and intermediate bodies. Elementary bodies (EB) are infectious particles that exist outside the host, whereas, reticulate bodies (RB) are formed from EB inside the host cell [3]. A susceptible bird can become infected through inhalation of airborne contaminated materials or through ingestion of contaminated foods. Human infection with $C p$. psittaci usually occurs due to inhalation of contaminated aerosol from dried feces or respiratory tract secretions of infected birds and desiccated dropping or dander. Vertical transmission of Chlamydophila was described in chickens, ducks, parakeets, sea gulls, snow geese and a number of wild birds [4-6].

Chlamydophila psittaci infections are most prevalent in psittacine birds including parakeets, love birds, cockatiels, amazon parrots, and macaws. Among non psittacine birds, infection was seen most commonly in dove and pigeons $[7,8]$. Young birds are more susceptible to infection than older birds.

Usual diagnosis is based on the isolation of the organism in cell cultures and chicken embryo and staining with special stains such as Giemsa, modified Gimenez and Castaneda, Macchiavello's [6]. In addition, stamp staining to identify the organism in impression smears from exudates, lesions or the surface of organs (liver or spleen) and swabs (cloacal, tracheal or conjunctival swabs) can also be used for identification. 
Cp. psittaci can be identified using speciesspecific conventional PCR which target the ompA or $16 \mathrm{~S}-23 \mathrm{~S}$ rRNA genes $[9,10]$. PCR is considered a valuable, specific, and sensitive method for the detection and differentiation of Chlamydia species [11]. Within Cp. psittaci, there are currently six serotypes (A to F) that infect birds and show host specificity. Serotypes $\mathrm{A}$ and $\mathrm{F}$ are specific for parrots, parakeets and budgerigars; B for pigeons; C for ducks and geese (water fowl); D for turkeys; and $\mathrm{E}$ are specific for pigeons, ducks, ostriches and rheas. Serovar A is routinely isolated from psittacine birds, in which it is associated with both acute and persistent infections [12,13].

This study was carried out for the isolation and identification of $C p$. psittaci from sparrows, doves, native and migratory quails, cocktails, finches, lovebirds and budgerigars using different methods. The pathogenicity of three selected strains isolated from pet birds, migratory quails and tree sparrows on chickens and quails was evaluated.

\section{Material and Methods}

\section{Birds}

A total of 145 birds (30 doves, 25 tree sparrows, 50 native and 40 migratory quails) and 38 pet birds (20 Budgerigars, 3 Finches, 5 Lovebirds and 10 Cocktails) were examined for the isolation of $C p$. psittaci from the internal organs (livers, lungs, heart). In addition, 70 (15 day old) Cobb chicks and 70 (15 day old quails) were used for the experimental pathogenicity of $C p$. psittaci.

\section{Cytological examination}

Impression smears prepared from the cut surfaces of the internal organs were air dried, fixed and stained with Giemsa stain as was previously described [14]. Stained slides were examined microscopically to detect chlamydial inclusion bodies.

\section{Chicken embryo inoculation}

Liver, heart and lungs were grinded in $10 \%$ suspension of PBS $[15,16]$. Aliquot of each prepared sample was inoculated into the yolk sac of 3 eggs $(0.2 \mathrm{~mL} / \mathrm{egg})$. Impression smears from the yolk sac were then prepared, and stained with Gimenez stain for the demonstration of $C p$. psittaci inclusions [17].

\section{Molecular identification of isolated Cp. psittaci}

Genomic DNA was extracted from yolk sacs using QIA amp DNA Mini Kit (Qiagen) according to the manufacture instructions. Primers targeting $1041 \mathrm{bp}$ of the major outer membrane protein (ompA) gene specific for $C p$. psittaci were used. The sequences of the primers are CPsitt-F 5 -GCT ACG GGT TCC GCT CT-3' and CPsitt-R 5'TTT GTT GAT YTGA ATCGAAGC-3' [18]. The amplification was carried out using Dream Taq $^{\text {TM }}$ PCR Master Mix (2X) and the primers construction was $100 \mathrm{pmole} / \mu \mathrm{L}$. The reaction conditions were an initial denaturation at $94^{\circ} \mathrm{C}$ for $5 \mathrm{~min}$, followed by 40 cycles of denaturation at $94^{\circ} \mathrm{C}$ for $5 \mathrm{~min}$, annealing at $55^{\circ} \mathrm{C}$ for $1 \mathrm{~min}$, extension at $72^{\circ} \mathrm{C}$ for $1 \mathrm{~min}$ and a final extension at $72^{\circ} \mathrm{C}$ for $7 \mathrm{~min}$. The PCR products were visualized by Electrophoresis in $1.5 \%$ agarose in $1 \mathrm{X}$ TAE and ethidium bromide was added to a concentration of $0.5 \mu \mathrm{g} / \mathrm{mL}$ [19].

\section{Experimental Pathogenicity}

Titration of Cp. psittaci strains on Embryonated chicken eggs (ECE)

Three isolates from pet birds, migratory quails, and tree sparrows were used for titration. The stock infected yolk material was diluted using 10 -fold serial dilution $\left(10^{-1}\right.$ up to $10^{-7}$ ) [20]. Only $0.2 \mathrm{~mL}$ of each dilution was inoculated in five ECEs and incubated at $37^{\circ} \mathrm{C}$. After 72 hours, any dead embryo was collected and yolk impression smears were prepared and stained with Gimenez stain and the titer was calculated [21].

Titration of $C p$. psittaci strains on tissue culture (vero cell)

Cell monolayer was prepared according to Vanrompay [22]. Tissue culture flask was inoculated with cells in growth media containing $10 \%$ fetal bovine serum then incubated at $37^{\circ} \mathrm{C}$. The flask was examined daily by inverted microscope for the cell growth. Inoculation of samples into cell culture was carried out according to McElnea and Cross [23], the strains were inoculated into 
yolk sac of 6 days old ECE 20\%.Tenfold serial dilution for each sample was done, then 0.2 $\mathrm{mL}$ of each specimen was added to each well of TC plate. Each sample was then inoculated into two wells then put in shaker for 1 hour and incubated at $37^{\circ} \mathrm{C}$. Cp. psittaci inclusion bodies were then detected in infected vero cells stained by Giemsa stain post $48-72 \mathrm{hrs}$. The tissue culture plates were examined microscopically for the presence of intracytoplasmic bodies and to detect cytopathic effect (CPF). The titer was then estimated using the formula described previously [21].

\section{Experimental design}

Seventy 15 days old commercial Cobb chicks and seventy 15 days old commercial quails were used for experimental infection with three recovered strains. Both chicks and quails were divided into 4 groups (1a, $2 \mathrm{a}$ and $3 a)$ for chicks and (1b, 2b and $3 b$ ) for quails. Each group contained 20 birds except the control group contained 10 only. The birds were infected by intra-tracheal route with 0.2 $\mathrm{mL}$ of $3 \mathrm{Cp}$. psittaci culture that contained $10^{6}$ TCID $_{50}$. Post infection (PI), birds were observed daily for 34 days for the clinical signs and lesions. One bird from each group was sacrificed daily for the first 10 days, then in days 14, 17, 21, 24, 28, 34 days PI. Samples from liver, lungs, heart, spleen, pancreas, pericardium, intestine, air sac, trachea and kidneys were collected and subjected to both impression smears and ECE inoculation for reisolation. Moreover, pharyngeal and cloacal swabs were collected for egg inoculation.

Table 1: Isolation percentage of $C p$. psittaci from wild and pet birds using different methods

\begin{tabular}{lccc}
\hline \multirow{2}{*}{ Bird (number) } & \multicolumn{3}{c}{ No. (\%) of positive birds by: } \\
\cline { 2 - 4 } & Giemsa & Gimenez & $\begin{array}{c}\text { Embryonic } \\
\text { death ratio }\end{array}$ \\
\hline Budgerigar (20) & $17(85 \%)$ & $17(85 \%)$ & $14(70 \%)$ \\
Lovebird (5) & $4(80 \%)$ & $5(100 \%)$ & $3(60 \%)$ \\
Finch (3) & $3(100 \%)$ & $3(100 \%)$ & $2(66.6 \%)$ \\
Cockatiel (10) & $8(80 \%)$ & $9(90 \%)$ & $6(60 \%)$ \\
Sparrow (25) & $16(64 \%)$ & $19(76 \%)$ & $15(60 \%)$ \\
Dove (30) & $23(76.6 \%)$ & $25(83.3 \%)$ & $21(70 \%)$ \\
Migratory quail (40) & $34(85 \%)$ & $38(95 \%)$ & $28(70 \%)$ \\
Native quail (50) & $36(72 \%)$ & $41(82 \%)$ & $34(68 \%)$ \\
\hline
\end{tabular}

\section{Molecular identification}

For the confirmation of $C p$. psittaci reisolation, one isolate was examined by PCR for the amplification of ompA gene. Sequencing of the amplified product was carried out using automated sequencer (ABI3730XL, DNA analyzer, Macrogen Inc., Seoul, Korea) Sequence identity was calculated using MegAlign software (DNA STAR $^{\circledR}$ Laser gene ${ }^{\circledR}$ version 7.2, USA). Phylogenetic tree was constructed by the neighbor-joining method employing the
Kimura 2-parameter model in MEGA6.06 software [24] by aligning 517 bp of representative lineage specific nucleotide sequences. The tree topology was evaluated by 1000 bootstrap replicates to estimate the robustness of tree branches. The reference sequences used for comparison and phylogenetic analysis were obtained from Gen Bank with accession numbers. The analyzed sequence was submitted to NCBI Gene Bank and accession number KY296311 was provided. 

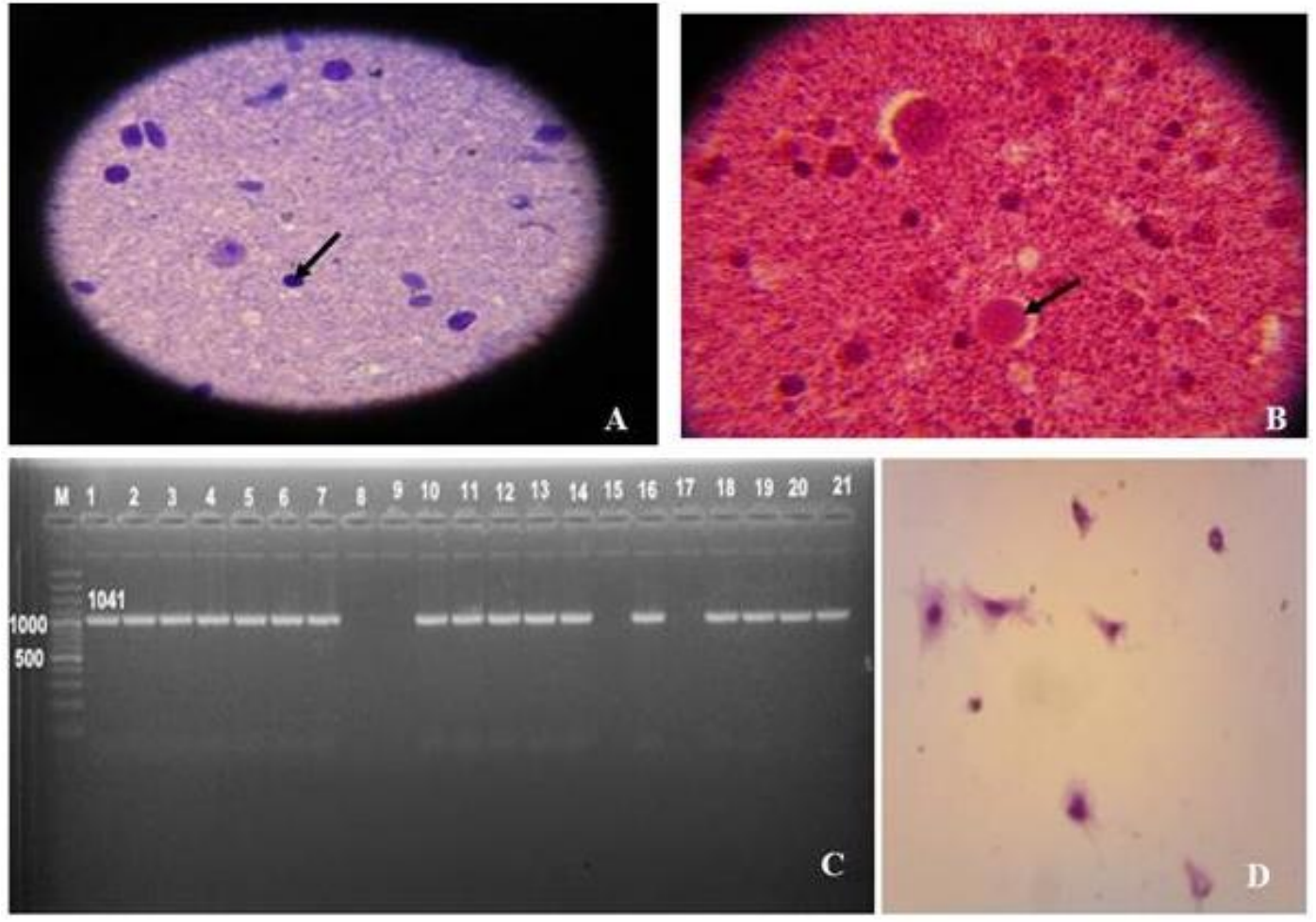

Figure 1: A: Elementary body in migratory quail liver stained by Giemsa (Black arrow), B: Inclusion bodies in yolk sac stained by Gimenez stain (Black arrow), C: Cytopathic effect, D: Exemplar of amplification of ompA gene (1041 bp) from Cp. psittaci isolates, M: 100 bp ladder, 1: positive control, (2-7, 10-14, 16, 18-21): positive samples, $(8-9,15,17)$ : negative samples.

\section{Results}

\section{Detection of Cp.psittaci}

Inclusion and elementary bodies were characterized in organ smears from the examined birds. Elementary bodies are small and dense body (Figure 1A), while inclusion bodies appeared as large vacuole. In case of wild birds, chlamydial inclusions were demonstrated using Giemsa stain in migratory quails $(85 \%)$, followed by doves $(76.6 \%)$, native quails in $(72 \%)$ and tree sparrows $(64 \%)$. While in pet birds, chlamydial inclusions were observed in finches $(100 \%)$ followed by Budgerigar (85\%), love birds $(80 \%)$ and Cockatiels (80\%) (Table 1). Examination of the samples by Gimenez stain reveal that in wild birds, chlamydial inclusions were demonstrated in migratory quails $(95 \%)$, followed by doves $(83.3 \%)$, native quails $(82 \%)$, and tree sparrows $(76 \%)$. In addition, the examination showed that in pet birds, $100 \%$ of finches and love birds, followed by Cockatiels (90\%) then Budgerigar (85\%), were positive (Figure 1B). Embryonic death ratio revealed that in wild birds the ratio was $60 \%$ in tree sparrows, $70 \%$ in dove and migratory quails and $68 \%$ in native quails. While, in pet birds, the ratio was $70 \%$ in budgerigars, $66.6 \%$ in finches and $60 \%$ in love birds and cockatiel (Table 1). Isolation from liver was higher in dove $(73 \%)$, than other species of wild birds, on otherwise, results of impression smears from lungs and hearts were high in migratory quails $(65 \%)$ and $(50 \%)$, respectively. In case of pet birds, results of impression smear of liver and lungs showed high ratio in finches $(100 \%)$ and $(66.6 \%)$, respectively. While, heart smears showed higher ratio in cocktails $(50 \%)$ (Table 2). Gimenez staining showed higher positive results followed by embryonic inoculation, and tissue smear staining with Giemsa.

\section{Molecular identification}

Representative number of positive samples with Giemsa and Gimenez stains $(n=50)$ were chosen for amplification of ompA gene. A total of 41 samples $(82 \%)$ were positive by PCR (6/8 of tree sparrows, 8/10 doves, 8/10 native quails, $9 / 10$ migratory quails, 4/5 
budgerigars, 2/2 finches, 2/2 love birds, 2/3 cockatiels), Figure (1C) shows 1041 bp of
ompA gene amplified amplicons from $C p$. psittaci isolates.

Table 2: Isolation percentages of $C p$ psittaci from different internal organs of examined wild and pet birds

\begin{tabular}{|c|c|c|c|c|c|c|c|c|c|}
\hline & & \multicolumn{4}{|c|}{ Wild birds } & \multicolumn{4}{|c|}{ Pet birds } \\
\hline & & $\begin{array}{c}\text { Tree } \\
\text { sparrow }\end{array}$ & Dove & Native quail & $\begin{array}{c}\text { Migratory } \\
\text { quail }\end{array}$ & Budgerigar & $\begin{array}{r}\text { Love } \\
\text { bird }\end{array}$ & Finch & Cockatiel \\
\hline Liver & + ve & $15(60 \%)$ & $22(73 \%)$ & $33(66 \%)$ & $24(60 \%)$ & $15(75 \%)$ & $4(80 \%)$ & $3(100 \%)$ & $7(70 \%)$ \\
\hline Lung & $+\mathrm{ve}$ & $12(48 \%)$ & $18(60 \%)$ & $30(60 \%)$ & $26(65 \%)$ & $10(50 \%)$ & $3(66 \%)$ & $2(66.6 \%)$ & $6(60 \%)$ \\
\hline Heart & $+v e$ & $10(40 \%)$ & $14(45 \%)$ & $25(50 \%)$ & $20(50 \%)$ & $8(40 \%)$ & $2(40 \%)$ & $1(33.3 \%)$ & $5(50 \%)$ \\
\hline
\end{tabular}

\section{Experimental Pathogenicity}

Titration of Cp. psittaci

Cytopathic effect of $C p$. psittaci in tissue culture was detected by recorded changes in the shape of tissue culture cells which transfer from spindle shape to round with destruction (Figure 1D).

Titration of 3 isolates from pet birds, migratory quail, tree sparrows in tissue culture were $6.15,6.34$ and 6.4 tissue culture infective dose $\left(\mathrm{TCID}_{50}\right.$ )and on embryonated chicken eggsthe titer was 6.16, 6.33 and 6.36 (embryo infective dose)EID $\mathrm{E}_{50}$ respectively.Therefor ,for the experimental pathogenicity, an infective dose of $10^{6}$ was used.

\section{Experimental infection}

In chicks, group 1a, birds showed unilateral ocular lesion and mucoid diarrhea. Moreover, all groups showed rapid breathing and sleepiness. Three weeks PI, all groups showed rapid breathing, sleepiness, ruffled feathers, weakness and some birds showed sneezing, gasping, and conjunctivitis (groups 1a and 3a). These signs were observed along the observation period. Postmortem examination revealed mild congestion in lung, liver, heart in group 1a. While, in group 3a, mild congestion in kidney was observed from 7-10 days PI. From 2-3 weeks PI in group 1a and 3a pericarditis, pancreatitis, intestine filled with fluid and liver enlarged, lung, spleen and muscle congested were observed. From 3 weeks all groups showed pericarditis, congested liver, congested lung heart, pericarditis, airsacculitis and intestine filled with fluid.

In quails, mucoid frothy diarrhea was observed 3-5 days PI in group $1 \mathrm{~b}$ and $3 \mathrm{~b}$ with unilateral ocular lesion in group $1 \mathrm{~b}$, while 3 weeks PI, all groups showed weakness, loss weight. In group1b, ocular lesions were clear and gasping was observed. Greenish and mucoid frothy diarrhea in groups $1 b$ and $2 b$ were observed. Postmortem examination showed that groups $1 \mathrm{~b}$ and $3 \mathrm{~b}$ showed congested lung and liver 2-4days PI. From 2-3 weeks PI birds in group $1 b$ and $3 b$ showed congested muscle, liver, lungs, spleen and hemorrhagic spots on the liver, pericarditis and enteritis. These signs were continuing along the experiment.

\section{Molecular identifocation}

For the confirmation of the re-isolation $C p$. psittaci from experimentally infected birds, stained smears with Gimesa and Gimenez stains were examined and also isolation of the organism in ECE was carried out. The smears showed chlamydial inclusion bodies and one isolate was randomly chosen for molecular identification by amplification of ompA gene. The amplicon was sequenced and the sequence analysis showed identity with $C p$. psittaci type A on the gene bank (Figures 2, 3). 


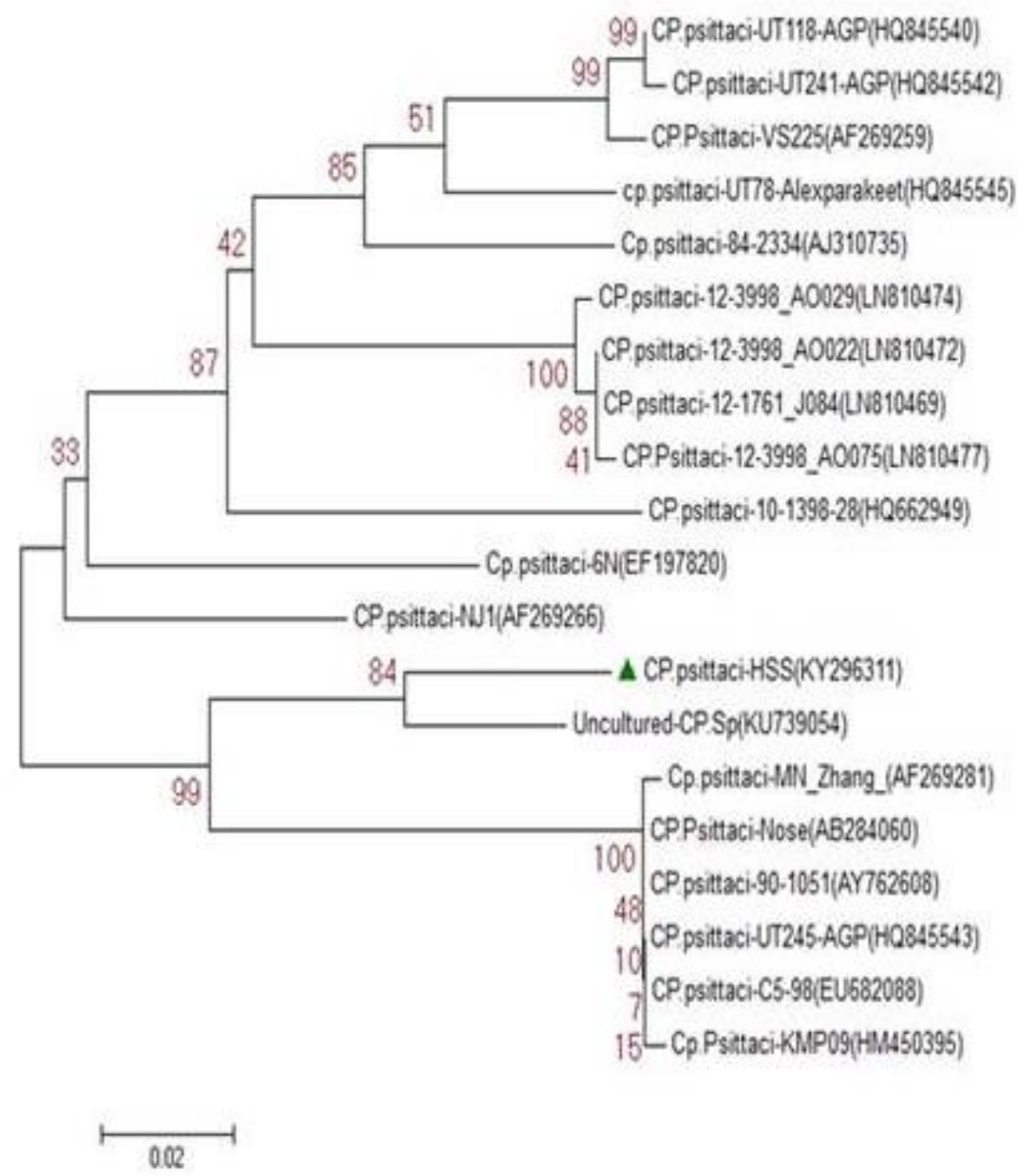

Figure 2:Phylogenetic analysis of ompA gene sequence of Chlamydophil apsittaciin psittacine birds. Other sequences were obtained from gene bank (accession numbers are indicated). Bootstrap values obtained from 1000 replications are shown at branch. The scale bar represents the number of substitutions for a unit branch length.

\section{Discussion}

$C p$. psittaci infection in birds (avian chlamydiosis) or humans (psittacosis) is an intracellular Gram-negative bacterium with vague clinical signs in infected birds and the organism is shed in feces and nasal/ocular discharge [2]. Cp. psittaci can infect a wide variety of native, wild birds and mammals including human [5,25]. One hundred and forty-five birds from four species of wild birds (30 doves, 25 tree sparrows, 50 native quails and 40 migratory quails and thirty-eight birds from 4 species of pet birds (20 budgerigars, 3 finches, 5 love birds, and 10 cockatiels were examined for the presence of $C p$. psittaci during the current study.

In this study, impression smears stained by Giemsa stain from different organs of wild birds showed high rates for Chlamydophila species $(72,85,64$ and $76.7 \%$, from native quails, migratory quails, tree sparrows and doves, respectively. Similarly, high rates of Chlamydophila species $(67.3 \%)$ from migratory birds was recorded previously in Egypt [26]. Moreover, EL -Jakee [27] recorded 81.8 and $77.4 \%$ prevalence rates for Chlamydophila species from cattle egret and hoopoe, respectively. In case of pet birds (budgerigars, love birds, finches, and 
cockatiels), high rates of Chlamydophila species were also recorded $(85,80,100$ and $80 \%$, respectively These results agree with a previous result recorded in Egypt [28]. On the other hand, Schwartz and Fraser [29] recorded lower rates of Chlamydophila species in cockatiels (26.9\%), love birds (21.4\%) and finches $(75.3 \%)$.

From the obtained results, it is clear that wild birds (Doves, tree sparrows, native quails and migratory quails) and pet birds (Budgerigar, finches, love birds, and cockatiels) are considered as natural hosts and they have a role in spreading infection by shedding the organism in their excretions [5].

Chlamydophila species inclusion bodies appeared as small, round, purple, red and blue dots which were the same observations reported in previous studies $[25,30]$.

The result of microscopical examination of suspected tissues revealed that liver was the most affected organ in tree sparrows, doves, native quails and migratory quails with isolation percentages of $60,73,66$ and $60 \%$, respectively. Meanwhile, the rates of Chlamydophila species in lung were lower than those obtained from liver in the same wild birds (48, 60, 60 and 65\%, respectively). Additionally, lower ratios of Chlamydia species were recorded from the heart $(40,46$, 50 and $50 \%$, respectively) (Table 2). These results are compatible with a previous study [31], where chlamydia was highly isolated from livers $(78 \%)$. On the other hand, Chlamydophila was highly recovered from liver of budgerigars, love birds, finches and cockatiels with percentages of 75, 80, 100 and $70 \%$, respectively and the percentages of isolation from the lung were 50, 66, 66.6 and $60 \%$, respectively. While lower percentage of isolation was from the heart 40\%, 40\%, 33.3\% and $50 \%$, respectively. The obtained results showed high incidence of infection (Table 2).

\begin{tabular}{|c|c|c|c|c|c|c|c|c|c|c|c|c|c|c|c|c|c|c|c|c|c|c|}
\hline \multicolumn{23}{|c|}{ Pucturtiones: } \\
\hline & 1 & 2 & 3 & 4 & 5 & 6 & 7 & 8 & 9 & 10 & "11 & 12 & 13 & 14 & is & 16 & 17 & 18 & 19 & 20 & & \multirow{3}{*}{ 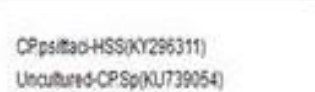 } \\
\hline 1 & & 947 & 921. & 828 & 830 & 828 & 921 & 921. & 921 & 919 & 807 & 923 & 817 & 828 & 828 & 828 & 826 & 245 & 829 & 807 & 1 & \\
\hline 2 & 55 & & 85.6 & 850 & 850 & 847 & 856 & 856 & 856 & 85.3 & 839 & 85.8 & 85.6 & 862 & 882 & 86.2 & 859 & 885. & 85.1 & 836 & 2 & \\
\hline 3 & 8.4 & 16.1 & & 1826 & 834 & 832 & 1000 & 1000 & 1000 & 998. & 803 & 998. & 813 & 824 & 322 & 822. & 819 & 835. & 829 & 801 & 3 & CPPsatadivase(LE2s4050) \\
\hline 4 & 196 & 968. & 2001 & & 980 & 97.6 & 826 & 825 & 82.6 & 324 & 943 & 824 & 927 & 901 & 903 & 903. & 901 & 890 & 85.1. & 882 & 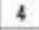 & CPPstud:VS225(AF269259) \\
\hline 5 & 194 & 168. & 989. & 21 & & 1996 & 834 & 834 & 234 & 832 & 941. & 832 & 899 & 003 & 901 & 90.1. & 892 & 884 & 25.1. & 87.9 & 5 & CPpstado-U118-AGPHCR4554) \\
\hline 6 & 196 & 172 & 192 & 25 & 0.4 & & 832 & 832 & 832 & 830 & 937 & 830 & 897 & 901 & 92.1 & 901. & 899 & 882 & 849 & 875 & 6 & 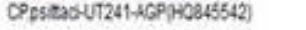 \\
\hline 1 & 84 & 161 & 00 & 200 & 189. & 102 & & 1000 & 1000 & 998 & 823 & 988 & 813 & 824 & 622 & 822 & 819. & 835 & 829 & 801 & 1 & Opsitadi-90-1051(46762506) \\
\hline 8 & 8.4 & 161 & 00 & 200 & 189 & 192. & 00 & & 1000 & 998 & 80.3 & 99.8 & 813 & 824 & 822 & 822. & 819 & 83.5 & 829 & 80.1 & 8 & CPpsitad-UT245-1CPHO645643\}) \\
\hline 9 & 84 & 16.1 & 00 & 200 & 189 & 192 & 00 & 00 & & 99.8 & 803. & 998 & 313 & 824 & 822 & 822 & 819 & 835 & 829 & 80.1 & 9 & 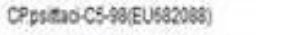 \\
\hline 10 & 88 & 164 & 02 & 202 & 182 & 194 & 02 & 02 & 02 & & 801. & 99.6 & 81.1 & 822 & 819 & 819 & 817 & 833 & 827 & 799 & 10 & 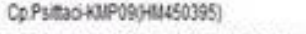 \\
\hline 11 & 223 & 182. & 230 & 59 & 62 & 6.6 & 230 & 230 & 230 & 232 & & 80.1 & 917 & 880 & 880. & 880 & $87 \mathrm{~B}$ & 87.1 & 85.7. & 888 & 11 & cF ostadUT778-Alerpsakeet410845545) \\
\hline 12 & 82 & 157 & 02 & 202 & 192 & 124 & 02 & 02 & 02 & 04 & 23.2 & & B1: & 8228 & 819 & 819 & 817 & 833. & 827 & 799 & 12 & Copstro-eidrang(4F282851) \\
\hline 13 & 210 & 161 & 216 & 100 & 150 & 112 & 216 & 215 & 216 & 218 & 8.9 & 21.8 & & 890 & 890 & 89.0 & 888 & 88.0 & 878 & 90,3 & 13 & Copstad-64-233e(N310735) \\
\hline 14 & 197 & 153 & 203 & 107. & 105 & 107 & 203 & 203 & 203 & 205 & 131 & 205 & 11.9 & & 992. & 992. & $990 \mid$ & 87.3 & 88.1 & $B 8 B$ & 14 & CPesicud-12.3988_A0029(N810476) \\
\hline 15 & 199 & 154 & 205 & 105 & 107 & 108 & 205 & 20.5 & 205 & 208 & 131. & 208 & 119 & 0.8 & & 1000 & 99.8 & 87.6 & 859. & 888 & 15 & 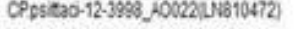 \\
\hline 16 & 197 & 154 & 205 & 105 & 107 & 10.8 & 20.5 & 20.5 & 205 & 20.8 & 131 & 208 & 119 & 08. & 0.0 & & 99.8 & 87.5 & 859 & 838 & 16 & 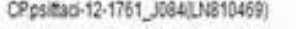 \\
\hline 17 & 198 & 157 & 20.8 & 107 & 110 & 110 & 208 & 208 & 208 & 211 & 133. & 21.1 & 121 & 10 & 0.2 & 02 & & 67.3 & 857 & 686 & 17 & CPPsitad-12-3898_ACO75(Natsam) \\
\hline 18 & 174 & 124 & 187 & 120 & 127 & 130 & 187 & 187. & 187 & 190 & 142 & 190 & 132 & 139 & 137 & 13.7 & 139) & & 90.1. & 888 & 18 & CPpsitaorUt:4F269266) \\
\hline 19 & 19.5 & 15.4 & 196. & 168 & 16.8 & 170 & 198 & 19.6 & 19.5 & 198 & 150 & 198 & 13.5 & 155 & 15.8 & 15.8 & 180 & 508 & & 87.1 & 19 & CDpstao-6MEF 197520) \\
\hline 20 & 224 & 186. & 233. & 129 & 133. & 13.5 & 233 & 233. & 233 & 235 & 121 & 236 & 105 & 121 & 121 & 121 & 124 & 122 & 142 & & 20 & CPpstad-10-135e-20(40852943) \\
\hline & 1 & 2 & 3 & 4 & 5 & 6 & 7 & 8 & 9 & 10 & 11 & 12 & 13 & 14 & 15 & 16 & 17 & 18 & 19 & 20 & & \\
\hline
\end{tabular}

Figure 3:Similarity table between ompA gene sequence of Chlamydophila psittaci in psittacine birds and other sequences were obtained from gene bank (accession numbers are indicated).

Moreover, in another study conducted in Hadia [28], the highest ratio of infection was recorded in liver samples of 93 and $100 \%$ Budgerigars and finches, respectively, while in lungs, the percentages were 40 and $0 \%$, respectively.
Embroynated chicken eggs inoculated with Chlamydophila species showed congestion of embryo and yolk sac vessels. Similar observations recorded previously [32]. By examination of Gimenez stained yolk sac membrane impression smear of infected 
chicken embryo by wild birds isolate, the percentage of infection was 76, 83.3, 82 and $95 \%$ in tree sparrows, doves, native quails and migratory quails, respectively. These results are in the same line with a previous study in Egypt conducted by El-Jakee [27], who analyzed Chlamydophila by using Gimenez stain for hoopoe and cattle egret and the positive ratios were 89.1 and $83 \%$, respectively.

In our study, psittacine birds and migratory birds showed the highest isolation ratios, followed by dove, native quails and finally tree sparrows as also observed previously in Britain [33], where the highest isolation ratio of Chlamydophila species was revealed_in psittacine birds, followed by doves.

PCR is used for diagnosis of $C p$. Psittaci using species specific conventional PCR and the ompA gene was investigated as a target DNA sequence among family Chlamydiacae [12,34]. In this study, 50 positive samples by Giemsa and Gimenez stains were randomly selected for PCR and 41 (82\%) were confirmed by ompA amplification. These results are similar to EL-Jakee [27] who recorded that results of PCR among hoope and cattle egret birds were 96.4 and $90.6 \%$, respectively. The current results showed that PCR was negative in 9 samples that showed inclusion bodies, this could be attributed to that inclusion bodies could be detected in organism other than Chlamydia. Celebi and Ak [35] recorded lower results for $C p$. Psittaci from pet birds $(34.4 \%)$ by PCR, when they used organ pools.

Titration of three selected isolates from pet birds, migratory quails, and tree sparrows for experimental infection was carried out on tissue culture (vero cell) which showed cytopathic effects and the titer was $10^{6}$ TCID50. This was in accordance to previously reported studies [36,37].

Experimentally infected chicks, exhibited general signs of illness, sleepiness, ruffled feathers, weakness, eye infection as unilateral or bilateral conjunctivitis in group1a and 3a. Furthermore, respiratory signs were observed in the form of rhinitis, sneezing, dyspnea, gasping with mucoid diarrhea at the first 10 days PI in some birds. These results are similar to those recorded previously [37], where the clinical signs observed in experimentally infected chicken in the form of respiratory signs as gasping, dyspnea and rhinitis were also investigated.

Postmortem examinations revealed that up to 10 days PI, mild congestion in lung, liver and heart were observed in group 1a, while in group $3 \mathrm{a}$, mild congestion in kidney was observed from 7-10 days PI. Post 2-3 weeks PI in groups 1a and $3 \mathrm{a}$, pericarditis, pancreatitis, filled intestine with fluid and enlarged liver, lung and spleen and muscle congestion were detected. These results agree with [38], who recorded slight congested liver, spleen, lung, and pericarditis. In quails, mucoid frothy diarrhea 3-5 days PI in groups $1 \mathrm{~b}$ and $3 \mathrm{~b}$ with unilateral ocular lesion in group1b was obtained herein, while 3 weeks PI, all groups showed weakness and loss weight. In group1b, ocular lesion was clear and gasping was recorded. Greenish and mucoid frothy diarrhea in groups $1 b$ and $2 b$ was observed. These signs were observed along the experiment. The same observed signs were recorded in a previous research [38].

Postmortem examination of infected quails revealed that groups $1 \mathrm{~b}$ and $3 \mathrm{~b}$ showed congested lung and liver 2-4 days PI. from 2-3 weeks PI, birds in groups $1 \mathrm{~b}$ and $3 \mathrm{~b}$ showed congested muscle, liver, lungs, spleen and hemorrhagic spots on the liver, pericarditis and enteritis. These signs were continuing along the experiment. Similar post mortem changes were recorded previously [38].

From the obtained results of experimental infection, the more pathogenic isolate was from pet birds then from other two isolates from chicken and quails. This result is in agreement with Takahashi et al. [39], who reported that strains isolated from psittacine birds were more virulent than the pigeon strains.

Sequence analysis of $O m p \mathrm{~A}$ gene fragment supported the classification of $C p$. psittaci into genotype A as mentioned previously [12]. The genotypes of $C p$. psittaci infection are relatively host specific and genotype $\mathrm{A}$ was the major genotype associated with parrot $[40,41]$. Our results demonstrated that the studied Cp. Psittaci/HSS (KY296311) strain 
which was isolated from pet birds (budgerigar) belongs to genotype $\mathrm{A}$ and presented high nucleotide homology (94\%) with the Egyptian uncultured strain isolated from song bird, 92.3\% with the Germany strain (MN Zhang) that was isolated from psittacine birds as recorded in a recent study in China [41]. In addition, it showed high nucleotide homology $(92.1 \%)$ with Iranian Strains Nose and UT245/AGP which was isolated from budgerigar and African grey parrot, respectively [42] in addition, homology with 90/1051 strain isolated from African grey parrot in Poland [43] was observed. Also, the nucleotide homology with the KMP09 strain isolated from psittacine birds in China was high (91.9\%) [44]., While, nucleotide homology of $80.7 \%$ with UT78-Alexandria parakeet (HQ 845545) as genotype J was also reported [42].

\section{Conclusion}

From this study, it was clear that wild and pet birds showed high incidence rates of $C p$. psittaci in their organs and excretions exposing other native birds, workers, and human dealing with pet birds to the risk of infection as $C p$. Psittaci has a major public health importance.

\section{Conflict of interest}

The authors declare no conflict of interest.

\section{References}

[1] Rzedzicki, J. and Tokarzewski, S. (2001): Birds as a potential source of human infection by Chlamydiae. Medycyna Weterynaryjna, 57 (7): 459-463

[2]West, A. (2011): A brief review of Chlamydophila psittaciin birds and humans. J Exotic Pet Med, 20(1): 18-20.

[3] Horn, M.; Collingro, A.; Schmitz-Esser, S.; Beier, C.L.; Purkhold ,U.' and Fartmann, B.; et al. (2004): Illuminating the evolutionary history of chlamydiae. Science, 304(5671): 728-730.

[4]Wittenbrink M.M., Mrozek, M. and Bisping, W. (1993): Isolation of Chlamydia psittaci from a chicken egg: evidence of egg transmission. Zoonoses and Public Health, 40(1-10), 451-452
[5]Andersen, A.A., Grimes, J.E. and Wyrick, P.B. (1997): Chlamydiosis (psittacosis, ornithosis). In: Diseases of poultry, $10^{\text {th }}$ Ed. (B.W. Calnek with H.J. Barnes, C.W. Beard, L.R. McDougald\& Y.M. Saif, eds). Iowa State University Press, Ames, 333-349.

[6]Dhama, K.; Chakraborty, S.; Tiwari, R. and Singh, S.D. (2013): Avian chlamydiosis (psittacosis/ornithosis): diagnosis, prevention and control, and its zoonotic concerns. Res Opin Anim Vet Sci, 3(6): 157-169.

[7]Dhlhousen, R.D. (2008): Sample submission guidelines for the molecular diagnosis of avian disease. Proceedings of the $29^{\text {th }}$ Annual Conference on Avian Medicine and Surgery, Mid- Atlantic States Association of Avian Veterinarians, Williamsburg, Virginia, USA, 31-36.

[8] Smith, K.A.; Campbell, C.T.; Murphy, J.; Stobierski, M.G. and Tengelsen, L.A. (2011): Compendium of measures to control Chlamydophila psittaci infection among humans (psittacosis) and pet birds (avian chlamydiosis), 2010 national association of state public health veterinarians (NASPHV). J Exot Pet Medicine, 20 (1): 32-45.

[9] Messmer, T.O.; Skelton, S.K.; Moroney, J.F.; Daugharty, H. and Fielbs, B.S. (1997): Application of a Nested, Multiplex PCR to Psittacosis Outbreaks. J Clin Microbiol, 35(8):2043-2046.

[10] Geens, T.; Desplanques, A.; Van Loock, M.; Bönner, B.M.; Kaleta, E.F.; Magnino, S.; Andersen, A.A.; Everett K.D.E. and Vanrompay, D. (2005): Sequencing of the Chlamydophila psittaciompA gene reveals a new genotype, $\mathrm{E} / \mathrm{B}$, and the need for a rapid discriminatory genotyping method. J Clin Microbiol, 43(5): 24562461.

[11]Krizek, I. and Prukner-Radovcic, E. (2009): Diagnostic chlamydiosis in birds. [Croatian]. VIII Symposium of Poultry Days 2009.Porec, Croatia, 25-28 March 2009, 88-97. 
[12]Andersen, A.A. (1997): Two new serovars of Chlamydia psittaci from North American birds. J Vet Diagn Invest, 9 (2): 159-164.

[13] Meijer, A. and Ossewaarde, J.M. (2002): Description of a wider diversity within the order Chlamydiales than currently classified. International Chlamydia Conference, Antalya, Turkey, P:16-21 ..

[14] Busby, D.W.; House, W. and Macdonald, J.R. (1964): Virology Techniques. London J. and A.C. grichill, Ltd.

[15] Anderson, A.A. and Tappe, J.P. (1989): Genetic, immunologic, and pathologic characterization of avian chlamydial strains. J Am Vet Med Assoc, 195(11): 1512-1516.

[16] Pierre, P. and Michel, T. (1993): Methods and Techniques in Virology. Marcel Dakker Inc., New York, Basel, Hong Kong.

[17]Giménez, D.F. (1964): Staining rickettsiae in yolk sac culture. Stain Technol., 39(3): 135-140.

[18] Heddema, E.R.; ter Sluis, S.; Buys, J.A.; Vandenbroucke-Grauls, C.M.; van Wijnen, J. H. and Visser, C. E. (2006): Prevalence of Chlamydiophila psittaci in fecal dropping from feral pigeons in Amsterdam, the NetherLands Appl Environ Microbiol, 72(6), 4423-4425.

[19]Sambrook, J.; Fritsh, E.F. and Maniatis, T. (1989): Molecular cloning. A Laboratory Manual. $2^{\text {nd }}$ Ed. Cold spring harbor Laboratory, press New York.

[20]Alethea, M. Fryzz,Sandra K. Conrad and Peg A. Patterson (2014): Supplemental Assay Method for Titration of Chlamydophila felis (formerly Feline Chlamydia psittaci) in embryonated chicken eggs. United States Department of Agriculture Center for Veterinary Biologics Testing Protocol. pp. 1-16.

[21]Reed, L.J. and Muench, H. (1938): A simple method for estimating fifty percent end point. Am J Hyg, 27(3): 493-497.

[22]Vanrompay, D.; Ducatelle, R. and Haesebrouck, F. (1992): Diagnosis of avian Chalmydiosis: specificity of modified Gimenez staining on smears and comparison of the sensitivity of isolation in eggs and three different cell culture. Zoonoses and Public Health, 39(1-10), 105-112.

[23] McElnea, C.L .and Cross, G.M. (1999): Methods of detection of Chlamydia psittaci in domesticated and wild birds. Aust Vet J., 77(8): 516-521

[24]Tamura, K.; Stechner, G.; Petersun, D.; Filipski, A. and Kumar, S. (2013): MEGA6:Molecular Evolutionary Genetics Analysis Version 6.0. Mol Biol Evol, 30(12): 2725-2729.

[25]OIE, (2012): Avian chlamydiosis. OIE Terrestrial Manual. pp. 1-13.

[26] Mousa, H.A.A. (1987): The possible role of migratory birds in the transmission of chlamydial and viral agents to man. Ph.D. Thesis, Faculty of Veterinary Medicine, Cairo University.

[27]El-Jakee, J.K.; Osman, K.M.; Ezzeldeen ,N.A.; Ali, H.A. and Mostafa, E.R. (2014):Chlamydia species in free-living Cattle Egret and Hoopoe in Egypt. Int $\mathbf{J}$ Vet Sci Med, 2(1): 1-6.

[28]Mousa, H.A.A. (1984): Incidence and public health importance of ornithosis and psittacosis in imported and exported love birds. M.V.Sc. Thesis, Faculty of Veterinary Medicine, Cairo University.

[29]Schwartz, J.C. and Fraser, W. (1981): Chlamydia psittaci infection in companion birds examined in Florida. Avian Dis, 26(1): 211-213.

[30]Andersen, A.A. (1996): Comparison of pharyngeal, fecal and cloacal samples for the isolation of Chlamydia psittaci from experimentally infected cockatiels and turkeys. J Vet Diagn Invest, 8(4): 448-450.

[31]Moore, F.M. and Petrak, M.L. (1985): Chlamydia immunoreactivity in birds with psittacosis: Localization of chlamydiae by the peroxidase-ntiperoxidase method. Avian Dis, 29 (4): 1036-1042.

[32]Bougioukris, P, Papaioannou, N, GeorgoPailou, I and Iordanidis, P.; 
Vlemmas, I.; Lekkas, S. and Siarkou, V. (2000): Chlamydia-induced bilateral ectopion of the inferior eye lids in pigeons. Avian Dis, 44: 372-378.

[33] Bevan, B.J. and Bracewell, C.D. (1986): Chlamydiosis in birds in Great Britain. 2. Isolation of Chlamydia psittaci from birds samples between 1976 and 1984. Epidemiol Infect, 96(3):453-458

[34] Geigenfeind I., Vanrompay D. and HaagWackernagel D. (2012): Prevalence of Chlamydia psittaci in the feral pigeon population of Basel, Switzerland. J Med Microbiol, 61(2): 261-265.

[35]Çelebi, B.S. and Ak, S. (2006): A comparative study of detecting Chlamydophila psittacI in pet birds using isolation in embryonated egg and polymerase chain reaction. Avian Dis, 50(4): 489-493.

[36]Vanrompay, D.; Andersen, A.A.; Ducatelle, R. and Haesebrouck, F. (1993): Serotyping of European isolates of Chlamydia psittaci from poultry and other birds. J Clin Microbiol, 31 (1): 134--137.

[37] Yin, L.; Lagae, S.; Kalmar, I.; Borel, N.; Pospischil, A. and Vanrompay, D. (2013): Pathogenicity of low and highly virulent Chlamydia psittaci isolates for specific pathogen-free chickens. Avian Dis, 57(2):242-247.

[38]Batta, M.K.; Asrani, R.K.; Katoch, R.C.; Sharma, M. and Joshi, V.B. (1999): Experimental studies of chlamydiosis in Japanese quails. Zentralblatt für Bakteriologie , 289(1): 47-52.
[39]Takahashi, T., Takahashina, I. and Hashimoto, N. (1988): A chicken model of systemic infection with $C$. psittaci: comparison of virulence among avian and mammalian strains. J Vet Sci, 50(3): 622631.

[40]Andersen, A.A. and Vanrompa, D. (2000): Avian chlamydiosis. Revue scientifique et technique (International Office of Epizootics) , 19 (2): 396-404.

[41] Zhang, N.Z, Zhang, X.X, Zhou, D.H.; Huang, S.Y.; Tian, W.P; Yang, Y.C.; Zhao, Q. and Zhu, X.Q. (2015): Seroprevalance and genotype of Chlamydia in pet Parrot in China .Epidemiol Infect, 143(1):55-61.

[42]Madani, .S.A. and Peighambari, S.M. (2013): PCR-based diagnosis ,molecular characterization and detection of atypical strains of avian Chlamydia psittaci in companion and wild birds. Avian Pathol, 42 (1):38-44

[43]Stenzel, T.; Pestka, D. and Choszcz, D. (2014): The prevalence and genetic characterization of Chlamydophila psittaci from domestic and feral pigeons in Poland and the correlation between infection rate and incidence of pigeon circovirus. Poultry science 93(12):3009-3016

[44]Feng, Y.; Feng, Y.; Zhang, Z.; Wu, S.; Zhong, D. and Liu, C. (2016): Prevalence and genotype of Chlamydia psittaci in faecal samples of birds from zoos and pet markets in Kunming, Yunnan, China. J Zhejiang Univ-Sci B (Biomed \& Bio technol), 17(4): 311-316. 


\section{الملخص العربي}

\section{دراسات عن عدوى الكلاميديا في بعض الطيور البرية وطيور الزينة}

أحمد محمد الصادق حجازي' ، مححد عباس السيسي' ، علا حسنين' ، هالة محمد نبيل طلبة' ، هبة عبد القادر باز '

$$
\text { 'قسم طب الطيور و الار انب ـ كلية الطب البيطرى - جامعة الزقازيق }
$$

rالمستشفي البيطري- كلية الطب البيطرى - جامعة الزقازيق

تعتبر الكلاميدوفيلا سيتاسي من أهم المسببات المرضية المشتركة في الطيور والتي تسبب مرض الكيات الكلاميديوزس. وتهدف هذه

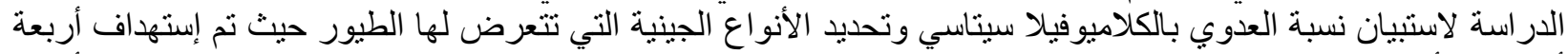

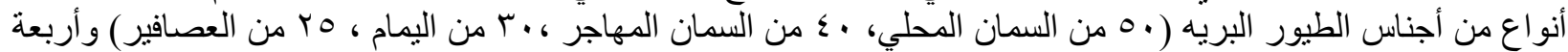

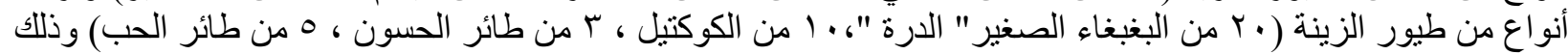

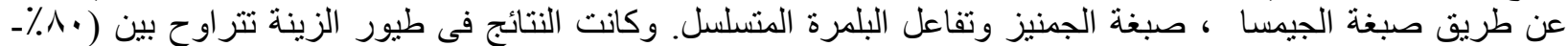

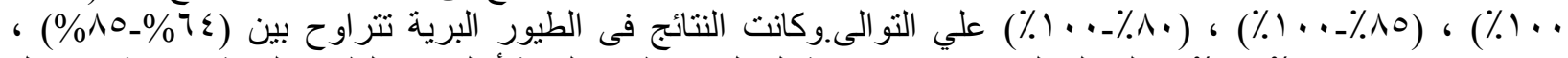

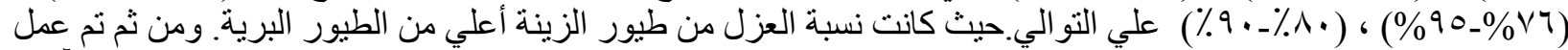

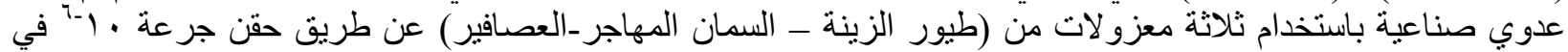

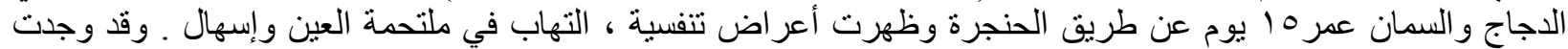

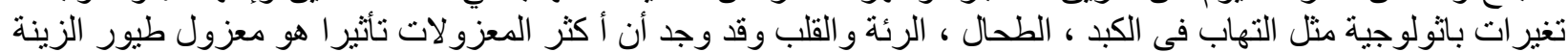

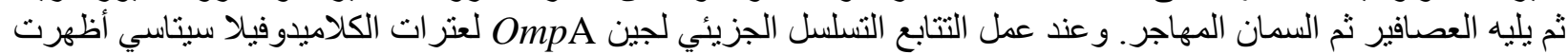

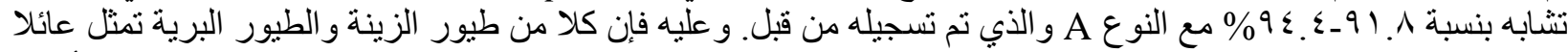

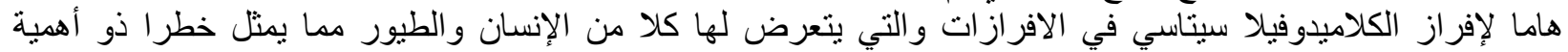

